\title{
PROTOTIPE WIND TUNNEL SEBAGAI KALIBRATOR ANEMOMETER PROTOTYPE WIND TUNNEL AS CALIBRATOR ANEMOMETER
}

\author{
Muhammad Reza Maulana Aliva ${ }^{l^{*}}$, Hapsoro A. Nugroho ${ }^{1}$ \\ ${ }^{\text {I} S e k o l a h ~ T i n g g i ~ M e t e o r o l o g i ~ K l i m a t o l o g i ~ d a n ~ G e o f i s i k a, ~ J a k a r t a ~}$ \\ *Email : rezaaliva7@gmail.com
}

\begin{abstract}
ABSTRAK
Informasi kecepatan angin merupakan salah satu parameter yang diperlukan BMKG yang diukur dengan menggunakan anemometer. Oleh karena itu diperlukan kalibrasi terhadap anemometer agar menghasilkan data kecepatan angin yang tepat dan akurat dengan menggunakan wind tunnel. Wind tunnel atau terowongan angin adalah suatu alat untuk melakukan studi dan penelitian mengenai interaksi antara gerakan udara dengan benda-benda yang ada didalam aliran udara. Wind Tunnel dalam kalibrasi perlatan meterorologi adalah alat kalibrator untuk kecepatan angin yang dapat menghasilkan angin laminar yang kecepatannya dapat dikontrol sehingga dapat digunakan untuk kalibrasi sensor kecepatan angin. Penelitian ini dilakukan untuk perancangan prototipe wind tunnel, dimana profil kecepatan angin diukur untuk mengetahui intensitas turbulensi dengan mengendalikan kecepatan motor kipas pada wind tunnel. Perancangan prototipe ini bertujuan untuk menunjang kegiatan belajar praktek kalibrasi peralatan meteorologi di STMKG agar taruna/i mengetahui proses kalibrasi anemometer menggunakan wind tunnel. Wind tunnel hasil rancangan dan implementasi memiliki panjang total $150 \mathrm{~cm}$ dengan intensitas tubulensi antara $3.11 \%$ sampai $6.55 \%$. Anemometer Casella dengan nilai koreksi $0.05 \mathrm{~m} / \mathrm{s}$ setelah proses kalibrasi digunakan sebagai standar dalam melakukan proses kalibrasi.
\end{abstract}

Kata Kunci : Wind tunnel, anemometer, kalibrasi, intensitas tubulensi

\begin{abstract}
Wind speed information is one of the required parameters of BMKG and is measured using an anemometer. Therefore, calibration of an anemometer is required to produce precise and accurate wind speed data using wind tunnel. Wind tunnel is a vehicle to studies and research on the interaction between air movement with objects in the air flow. Wind Tunnel in calibration of meterorologi equipment is a calibrator for wind speed which can produce laminar wind which its speed can be controlled so that it can be used for wind speed sensor calibration. This research was conducted to design the wind tunnel prototype, where the wind velocity profile is measured to know the intensity of turbulence by controlling the speed of fan motor in wind tunnel. The design of this prototype aims to support the learning activity of calibration practice of meteorology equipment in STMKG so that cadets know the calibration process of anemometer using wind tunnel. The design and implementation wind tunnel has a total length of $150 \mathrm{~cm}$ with intensity of turbulence between $3.11 \%$ to $6.55 \%$. Casella anemometer with a correction $0.05 \mathrm{~m} / \mathrm{s}$ after the calibration process is used as a standard in performing the calibration process.
\end{abstract}

Keyword : Wind tunnel, anemometer, calibration, intensity of turbulence 


\section{PENDAHULUAN}

BMKG berdasarkan Undang-Undang No. 31 Tahun 2009 tentang MKG memiliki beberapa kegiatan operasional seperti pengamatan meteorologi dan iklim, salah satu unsur dalam pengamatan tersebut adalah kecepatan angin. Pengamatan kecepatan angin menggunakan anemometer sebagai peralatan pengamatan. Undang-undang tersebut juga mengatur bahwa peralatan Meteorologi, Klimatologi, dan Geofisika di lingkungan BMKG harus laik operasi, oleh karena itu peralatan harus dikalibrasi. Hal itu juga diperkuat dalam Peraturan Pemerintah Nomor 46 Tahun 2012 tentang Penyelenggaraan Pengamatan dan Pengolahan Data Meteorologi, Klimatologi yang menyatakan bahwa "Untuk menjamin laik operasi, peralatan pengamatan wajib dilakukan Kalibrasi”. Kalibrasi anemometer dilakukan secara berkala menggunakan wind tunnel, dimana kecepatan angin dalam tunnel dapat diatur yang kemudian dibandingkan dengan kecepatan angin yang terukur oleh anemometer yang akan dikalibrasi.

Wind tunnel dalam kalibrasi peralatan meterorologi adalah media kalibrasi untuk kecepatan angin yang dapat menghasilkan angin laminar yang kecepatannya dapat dikontrol sehingga dapat digunakan untuk kalibrasi sensor kecepatan angin. Wind tunnel terdiri dari beberapa bagian yaitu: settling chamber, contraction cone, test section, diffuser dan drive section. Perancangan prototipe ini menggunakan motor listrik dan fan yang dapat diatur kecepatan yang terletak di drive section untuk menghasilkan hembusan angin di dalam wind tunnel.

Tujuan dalam perancangan wind tunnel ini antara lain: merancang dan membuat prototipe wind tunnel sebagai kalibrator anemometer, mengetahui desain wind tunnel yang baik agar menghasilkan aliran udara yang seragam dengan tingkat turbulensi serendah mungkin, dan menghitung tingkat intensitas turbulensi di dalam wind tunnel.

Manfaat yang diharapkan dari penelitian ini antara lain: penunjang kegiatan belajar mengajar praktek kalibrasi peralatan meteorologi di STMKG, menambah ilmu pengetahuan mengenai desain wind tunnel yang baik, dan menambah ilmu pengetahuan tentang tata cara pengukuran tingkat turbulensi aliran udara di dalam wind tunnel.

\subsection{Kalibrasi}

Kalibrasi adalah kegiatan yang menghubungkan nilai yang ditunjukkan oleh instrumen/alat ukur atau nilai yang diwakili oleh bahan ukur dengan nilai yang sudah diketahui tingkat kebenarannya (yang berkaitan dengan kisaran yang diukur) dalam kondisi tertentu menurut International Organization for Standardization (ISO) / International Electrotenic Comiton (IEC) Guide 17025 : 2005 dan Vocabulary of International Metrology (VIM) (Marpaung, 2015).

\subsection{Angin}

Angin adalah udara yang bergerak karena perbedaan tekanan di permukaan bumi. Angin akan bergerak dari suatu daerah yang memiliki tekanan tinggi ke daerah yang memiliki tekanan yang lebih rendah. Angin yang bertiup di permukaan bumi terjadi akibat adanya perbedaan penerimaan radiasi matahari, sehingga mengakibatkan perbedaan suhu udara. Perbedaan suhu tersebut menyebabkan perbedaan tekanan, akhirnya menimbulkan gerakan udara. Perubahan panas antara siang dan malam merupakan gerak utama sistem angin harian, karena beda panas yang kuat antara udara di atas darat dan laut atau antara udara di atas tanah tinggi (pegunungan) dan tanah rendah (lembah) (Tjasyono H.K., 2012).

\subsection{Anemometer}

Anemometer adalah suatu alat (instrumen) yang digunakan untuk mengukur arah dan kecepatan angin. Anemometer dapat dibagi dalam dua kategori yaitu alat untuk mengukur kecepatan (velocity) dari angin dan alat untuk mengukur tekanan dari angin.

\subsection{Wind Tunnel}

Wind tunnel merupakan peralatan uji berbentuk terowongan dimana udara dipaksa melaju dengan kecepatan yang diatur untuk mempelajari efek aliran aerodinamis dari suatu benda (Shaleh, 2015). Wind tunnel diklasifikasikan menjadi dua tipe yaitu tipe terbuka dan tipe tertutup. Perancangan ini menggunakan tipe terbuka dengan bagian utama terdiri dari settling chamber, contraction cone, test section, diffuser dan drive section. 


\subsubsection{Settling Chamber}

Bagian ini terdiri dari screen yang berbentuk saringan kawat dan honeycomb yang berbentuk sarang lebah. Honeycomb berfungsi mengurangi tingkat tubulensi dan ketidakseragaman aliran udara yang masuk menurut Mehta dan Bradshaw. Mehta dan Bradshaw juga merekomendasikan rasio antara panjang dan diameter cell honeycomb berkisar antara 7 sampai 10 (Cattafesta dkk., 2010).

Screen dipasang memecah turbulensi udara yang masuk sehingga tinggat turbulensi dapat dikurangi menurut Spangenberg dan Klebanoff (Cattafesta dkk., 2010).

\subsubsection{Contraction cone}

Ukuran dan bentuk dari contraction cone menentukan tingkat turbulensi akhir di bagian test section menurut Derbunivich dkk. (Cattafesta dkk., 2010). Fungsi dari contraction cone adalah mempercepat aliran udara dari settling chamber menuju test section dan membantu mengurangi ketidakseragaman dan tingkat turbulensi aliran udara yang masuk ke test section.

Percepatan, ketidakseragaman, dan tingkat tubulensi aliran udara tergantung pada rasio kontraksi, yakni rasio luas penampang pada saat masuk dan keluar contraction cone.

\subsubsection{Test section}

Test section merupakan bagian dimana model yang akan diuji ditempatkan. Oleh karena itu kecepatan yang diingkan dan kualitas aliran udara harus menjadi perhatian utama dalam perancangan sebuah wind tunnel.

\subsubsection{Diffuser}

Diffuser merupakan bagian wind tunnel yang terletak antara test section dan driver section. Bagian ini bertujuan untuk memperlambat aliran udara yang tinggi dari test section sehingga mencapai pemulihan tekanan statis dan mengurangi beban sistem drive (Cattafesta dkk., 2010).
Barlow, Rae, dan Pope menyatakan bahwa untuk diffuser berbentuk kerucut dengan perbedaan setengah sudut dinding diffuser kurang dari $3.5^{\circ}$ untuk desain yang baik. Mehta menyatakan bahwa sudut diffuser termasuk untuk diffuser berbentuk kerucut antara $5^{\circ}$ (untuk kemampatan aliran terbaik) dan $10^{\circ}$ (untuk pemulihan tekanan terbaik) (Cattafesta dkk., 2010).

\subsubsection{Drive section}

Drive section merupakan bagian dari wind tunnel yang terdiri dari fan dan motor listrik yang bertujuan untuk menjaga kecepatan aliran udara dalam wind tunnel tetap konstan. Motor listrik merupakan suatu perangkat elektromagnetis yang mengubah energi listrik menjadi energi mekanik. Motor listrik yang digunakan adalah motor induksi satu fasa.

\section{PERANCANGAN SISTEM}

\subsection{Blok diagram}

Blok diagram dalam sistem wind tunnel terdiri dari 5 bagian mulai dari awal udara masuk sampai udara keluar dan 1 bagian kontrol motor yang ditunjukan pada gambar 2.1 berikut:

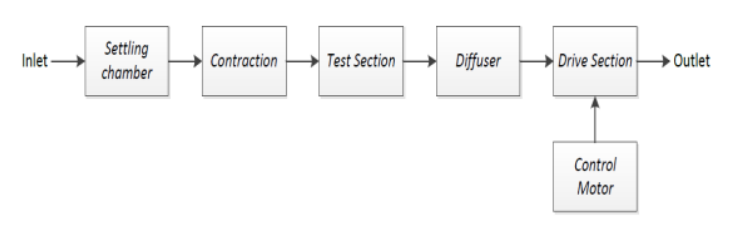

Gambar 2.1 Blok diagram sistem

\subsection{Diagram alir sistem}

Diagram alir sistem akan menjelaskan mulai dari proses inisialisasi port sensor kecepatan angin Casella dan modul infrared, menyalakan drive section, mengatur kecepatan drive section, bagian-bagian wind tunnel yang dilewati aliran udara, sampai pengolahan data kecepatan aliran udara dan putaran fan dan motor listrik di drive section oleh mikrokontroler. Diagram alir sistem dapat dilihat pada gambar 3.3 berikut: 


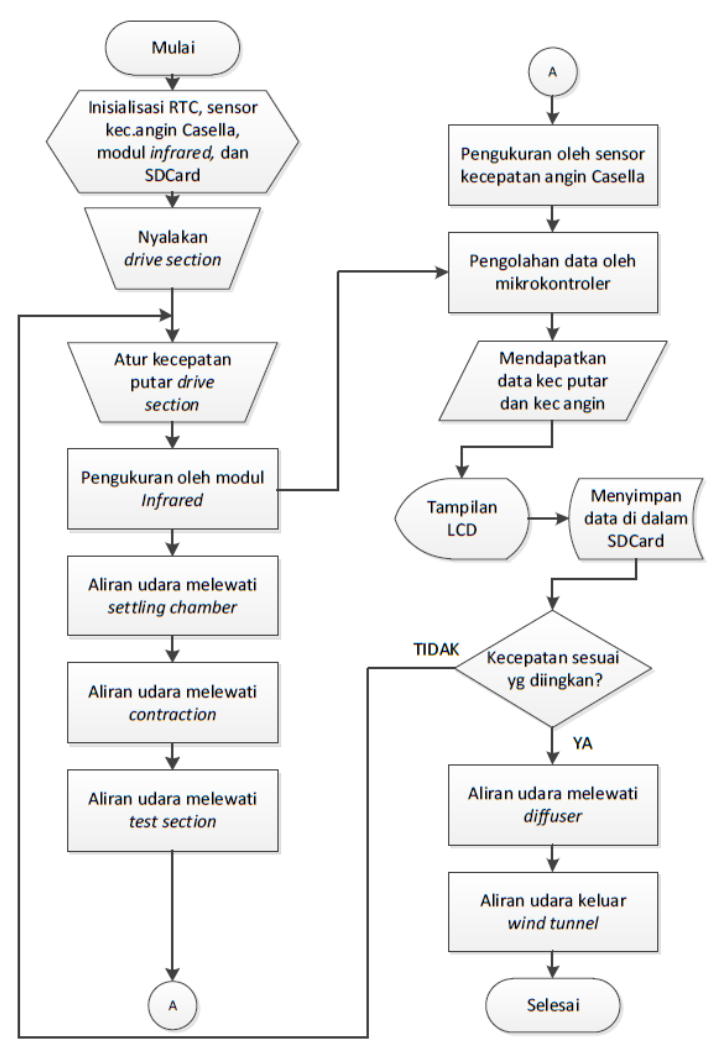

Gambar 2.2 Diagram alir sistem

\subsection{Perancangan wind tunnel}

Perancangan sistem wind tunnel berupa wind tunnel tipe terbuka yang terdiri dari 5 bagian utama yaitu: settling chamber, contraction cone, test section, diffuser dan drive section, dengan penjelasan sebagai berikut:

\subsubsection{Settling chamber}

Settling chamber dirancang dengan ukuran 80 $\mathrm{cm} \times 80 \mathrm{~cm}$ berdasarkan ukuran contraction dan panjang $15 \mathrm{~cm}$ berdasarkan ukuran honeycomb. Cell honeycomb dengan bahan pipa pvc berukuran diameter $1.5 \mathrm{~cm}$ dan panjang 12 $\mathrm{cm}$ dengan rasio antara panjang dan diameter sebesar 7, sesuai dengan rasio yang direkomendasikan yaitu antara 7 sampai 10 .

\subsubsection{Contraction cone}

Contraction cone dirancang dengan ukuran penampang masuk sebesar $80 \mathrm{~cm} \times 80 \mathrm{~cm}$ dan penampang keluarannya sebesar $40 \mathrm{~cm} \times 40$ $\mathrm{cm}$ sesuai dengan ukuran test section dengan panjang $20 \mathrm{~cm}$. Perbandingan luas penampang masuk dan luas penampang keluar (contraction ratio) sebesar 4 (6400:1600), sesuai dengan rasio kontraksi yang direkomendasikan yaitu 4 sampai 6. Bahan yang digunakan adalah stainless steel dengan tebal $0.8 \mathrm{~mm}$.

\subsubsection{Test section}

Test section dirancang dengan ukuran $40 \times 40$ $\mathrm{cm}$ dengan panjang $40 \mathrm{~cm}$. Bahan yang digunakan untuk membuat bagian ini adalah akrilik bening dengan ketebalan $5 \mathrm{~mm}$ agar pengamatan alat diuji mudah dilakukan.

\subsubsection{Diffuser}

Diffuser dirancang dari bahan plat stainless steel dengan tebal $0.8 \mathrm{~mm}$. Penampang masukan berbentuk persegi dengan ukuran 40 $\mathrm{cm} \times 40 \mathrm{~cm}$ sesuai dengan ukuran test section, penampang keluaran juga berbentuk persegi dengan ukuran $50 \mathrm{~cm} \times 50 \mathrm{~cm}$ sesuai dengan diameter fan, dan panjangnya $40 \mathrm{~cm}$. Sudut diffusion $(\theta)$ yang dibentuk sebesar arctan $(5 / 40)=7^{\circ}$, sesuai dengan sudut diffusion yang direkomendasikan sebesar $5^{\circ}$ sampai $10^{\circ}$.

\subsubsection{Drive section}

Drive section yang digunakan dalam perancangan ini adalah tube axial fan karena memiliki housing fan berbentuk tabung dan menghasilkan aliran fluida dengan tekanan rendah dan jumlah volume udara besar. Ukuran fan 20 inch / $50 \mathrm{~cm}$ seperti gambar 3.13, kecepatan $1400 \mathrm{rpm}$, air flow 3345 CFM, dan motor 1 phase dengan daya 200 watt.

\section{IMPLEMENTASI SISTEM}

Implementasi sistem wind tunnel berupa wind tunnel tipe terbuka yang terdiri dari 5 bagian utama yaitu: settling chamber, contraction cone, test section, diffuser dan drive section, dengan penjelasan sebagai berikut:

\subsection{Settling chamber}

Settling chamber dibuat dengan ukuran $40 \mathrm{~cm}$ $\times 40 \mathrm{~cm}$ dan panjang $15 \mathrm{~cm}$. Cell honeycomb dibuat menggunakan bahan pipa kabel dengan diameter $1,5 \mathrm{~cm}$ dan panjang $12 \mathrm{~cm}$. Screen dibuat dari kawat mesh diameter $1 \mathrm{~mm}$. Perbedaan implementasi dengan perancangan berdasarkan pertimbangan ketersediaan bahan dan kemudahan membuatnya tanpa mengurangi kinerja atau fungsi dari settling chamber itu sendiri. 


\subsection{Contraction cone}

Contraction cone dibuat dengan ukuran penampang masuk sebesar $80 \mathrm{~cm} \times 80 \mathrm{~cm}$ dan penampang keluarannya sebesar $40 \mathrm{~cm} \times 40$ $\mathrm{cm}$ dengan panjang $45 \mathrm{~cm}$. Bahan yang digunakan adalah fiberglass. Perbedaan implementasi dengan perancangan berdasarkan pertimbangan biaya pembuatan dan bahan fiberglass lebih ringan.

\subsection{Test section}

Test section dirancang dengan ukuran $40 \times 40$ $\mathrm{cm}$ dengan panjang $45 \mathrm{~cm}$. Bahan yang digunakan untuk membuat bagian ini adalah akrilik bening dengan ketebalan $5 \mathrm{~mm}$.

\subsection{Diffuser}

Diffuser dibuat dengan ukuran penampang masukan berbentuk persegi dengan ukuran 40 $\mathrm{cm} \times 40 \mathrm{~cm}$, penampang keluaran dibuat berbentuk lingkaran diameter $50 \mathrm{~cm}$ sesuai dengan diameter fan, dan panjangnya $43 \mathrm{~cm}$. Bahan yang digunakan fiberglass.

Perbedaan implementasi dengan perancangan berdasarkan pertimbangan biaya pembuatan, mempermudah penyambungan dengan drive section, dan bahan fiberglass lebih ringan tanpa mempengaruhi sudut diffusion atau bukaan yang dirancang.

\subsection{Drive section}

Drive section yang digunakan adalah tube axial fan dengan ukuran fan 20 inch / $50 \mathrm{~cm}$ dengan panjang $27 \mathrm{~cm}$, kecepatan $1400 \mathrm{rpm}$, air flow 3345 CFM, dan motor 1 phase dengan daya 350 watt.

Bagian-bagian dari sistem wind tunnel di atas akan dipasang mulai dari bagian aliran udara masuk sampai bagian aliran udara keluar dengan panjang total $150 \mathrm{~cm}$ dengan implementasi seperti yang ditunjukkan gambar 3.23 (a), (b), dan (c) berikut:
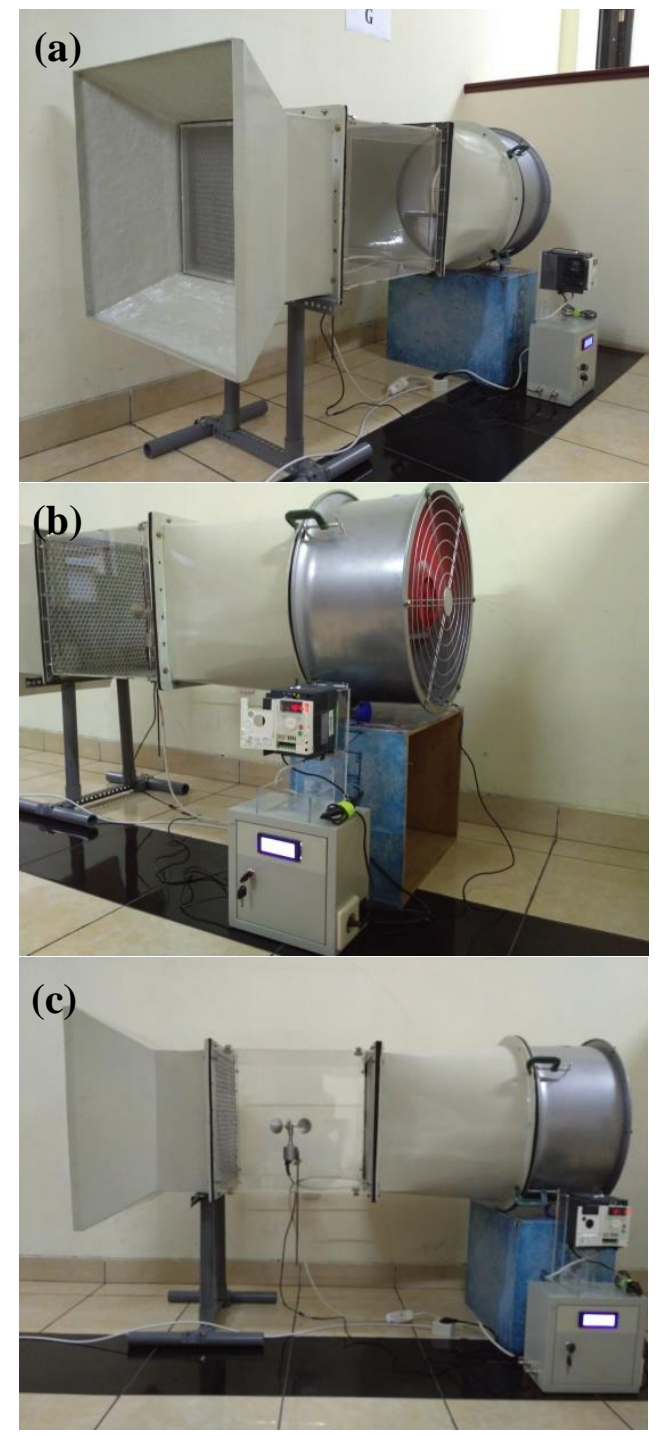

Gambar 3.23 Implementasi wind tunnel keseluruhan (a) tampak depan (b) tampak belakang dan (c) tampak samping.

\section{PENGUJIAN DAN ANALISIS}

Pengujian sistem dilakukan untuk mengetahui apakah sistem telah bekerja dengan baik atau tidak. Pengujian dilakukan dengan mengukur kecepatan angin di dalam test section wind tunnel dengan titik uji yang telah ditentukan. Pengujian dilakukan pada tanggal 3 Agustus 2017 sampai 10 Agustus 2017 di lantai 2 perpustakaan kampus STMKG. 


\subsection{Uji titik test section}

Pengujian titik di test section wind tunnel dilakukan dengan mengukur kecepatan angin pada bagian dan titik tertentu menggunakan anemometer GM816. Sebaran titik uji dapat dilihat pada gambar 4.1, posisi titik uji dapat dilihat pada gambar 4.2, dan proses pengujian titik menggunakan anemometer GM816 dapat dilihat pada gambar 4.3.

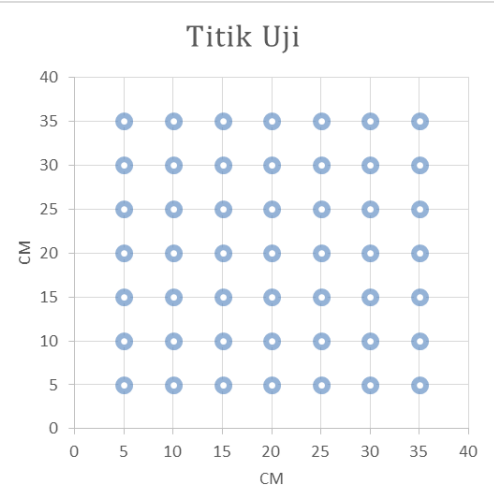

Gambar 4.1 Sebaran titik uji

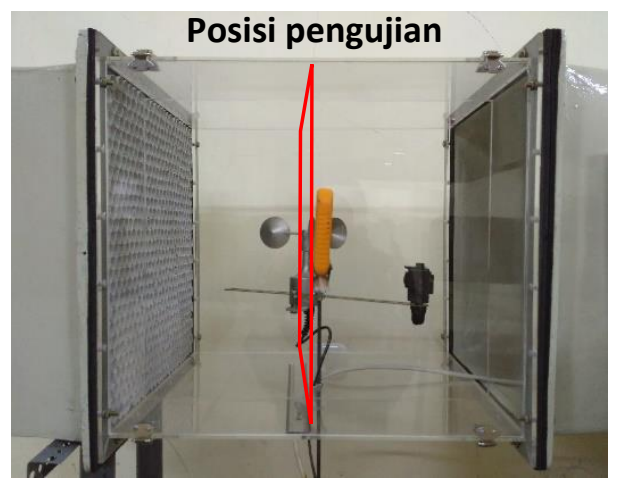

Gambar 4.2 Posisi uji titik

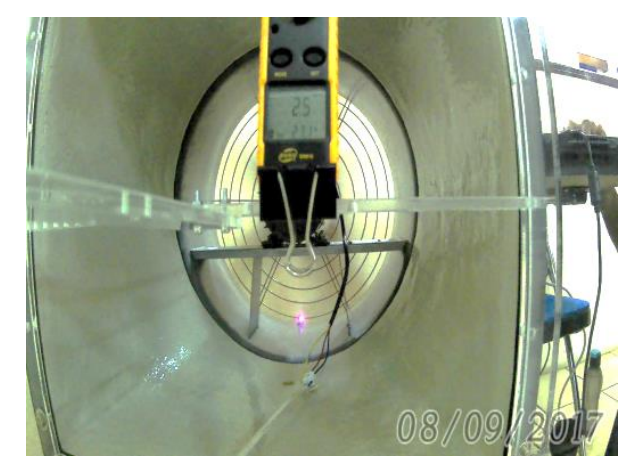

Gambar 4.3 Proses pengujian menggunakan anemometer GM816

Pengujian dilakukan dengan meletakkan anemometer GM816 pada bagian uji dan anemometer Casella pada bagian tengah test section. Kecepatan angin diatur sampai pembacaan anemometer Casella (standar) menunjukkan set point tertentu. Hasil pengujian titik bagian 2 dengan set point 2 $\mathrm{m} / \mathrm{s}, 3 \mathrm{~m} / \mathrm{s}, 4 \mathrm{~m} / \mathrm{s}, 5 \mathrm{~m} / \mathrm{s}$, dan $6 \mathrm{~m} / \mathrm{s}$ dapat dilihat pada tabel 4.1. Data hasil pengujian tersebut digambarkan dalam bentuk grafik pada gambar 4.4 untuk melihat profil kecepatan setiap ketinggian.

Tabel 4.1 Data hasil pengujian titik.

\begin{tabular}{|c|c|c|c|c|c|c|c|c|}
\hline \multirow{2}{*}{$\begin{array}{l}\text { Kecepatan } \\
\text { Angin }\end{array}$} & \multirow{2}{*}{\begin{tabular}{|c} 
Tinggi \\
Titik (cm)
\end{tabular}} & \multicolumn{7}{|c|}{ Jarak Titik $(\mathrm{cm})$} \\
\hline & & 5 & 10 & 15 & 20 & 25 & 30 & 35 \\
\hline \multirow{7}{*}{$2.04 \mathrm{~m} / \mathrm{s}$} & 35 & 1.50 & 1.60 & 1.60 & 1.58 & 1.53 & 1.60 & 1.55 \\
\hline & 30 & 1.58 & 1.68 & 1.68 & 1.70 & 1.75 & 1.78 & 1.68 \\
\hline & 25 & 1.65 & 1.75 & 1.75 & 1.78 & 1.80 & 1.73 & 1.65 \\
\hline & 20 & 1.65 & 1.80 & 1.88 & 1.98 & 1.95 & 1.75 & 1.65 \\
\hline & 15 & 1.60 & 1.70 & 1.75 & 1.85 & 1.78 & 1.75 & 1.63 \\
\hline & 10 & 1.60 & 1.68 & 1.65 & 1.70 & 1.75 & 1.78 & 1.70 \\
\hline & 5 & 1.50 & 1.60 & 1.60 & 1.58 & 1.50 & 1.60 & 1.55 \\
\hline \multirow{7}{*}{$3.01 \mathrm{~m} / \mathrm{s}$} & 35 & 2.50 & 2.58 & 2.60 & 2.58 & 2.50 & 2.65 & 2.55 \\
\hline & 30 & 2.58 & 2.60 & 2.65 & 2.65 & 2.75 & 2.70 & 2.55 \\
\hline & 25 & 2.60 & 2.85 & 2.95 & 3.00 & 2.85 & 2.80 & 2.65 \\
\hline & 20 & 2.65 & 2.75 & 2.95 & 3.00 & 2.95 & 2.78 & 2.58 \\
\hline & 15 & 2.60 & 2.80 & 2.98 & 2.95 & 2.80 & 2.78 & 2.65 \\
\hline & 10 & 2.60 & 2.60 & 2.65 & 2.65 & 2.75 & 2.70 & 2.55 \\
\hline & 5 & 2.50 & 2.60 & 2.63 & 2.55 & 2.50 & 2.65 & 2.55 \\
\hline \multirow{7}{*}{$4.06 \mathrm{~m} / \mathrm{s}$} & 35 & 3.50 & 3.55 & 3.65 & 3.65 & 3.53 & 3.55 & 3.50 \\
\hline & 30 & 3.60 & 3.68 & 3.70 & 3.75 & 3.75 & 3.75 & 3.70 \\
\hline & 25 & 3.55 & 3.80 & 4.00 & 3.98 & 3.85 & 3.75 & 3.70 \\
\hline & 20 & 3.75 & 3.88 & 4.05 & 4.08 & 4.10 & 3.90 & 3.73 \\
\hline & 15 & 3.65 & 3.85 & 4.00 & 3.95 & 3.90 & 3.85 & 3.75 \\
\hline & 10 & 3.60 & 3.68 & 3.73 & 3.85 & 3.78 & 3.78 & 3.70 \\
\hline & 5 & 3.50 & 3.55 & 3.68 & 3.60 & 3.50 & 3.55 & 3.50 \\
\hline \multirow{7}{*}{$5.04 \mathrm{~m} / \mathrm{s}$} & 35 & 4.20 & 4.35 & 4.55 & 4.55 & 4.45 & 4.43 & 4.23 \\
\hline & 30 & 4.50 & 4.60 & 4.73 & 4.90 & 4.85 & 4.60 & 4.60 \\
\hline & 25 & 4.40 & 4.70 & 4.85 & 4.93 & 4.90 & 4.78 & 4.65 \\
\hline & 20 & 4.65 & 4.80 & 5.00 & 5.13 & 5.10 & 4.90 & 4.60 \\
\hline & 15 & 4.55 & 4.70 & 4.90 & 4.93 & 4.90 & 4.80 & 4.65 \\
\hline & 10 & 4.50 & 4.60 & 4.70 & 4.78 & 4.83 & 4.60 & 4.60 \\
\hline & 5 & 4.20 & 4.30 & 4.55 & 4.55 & 4.40 & 4.45 & 4.23 \\
\hline \multirow{7}{*}{$6.01 \mathrm{~m} / \mathrm{s}$} & 35 & 5.00 & 5.20 & 5.45 & 5.38 & 5.30 & 5.23 & 5.05 \\
\hline & 30 & 5.35 & 5.50 & 5.65 & 5.78 & 5.75 & 5.50 & 5.35 \\
\hline & 25 & 5.30 & 5.65 & 5.85 & 5.83 & 5.75 & 5.58 & 5.45 \\
\hline & 20 & 5.50 & 5.75 & 5.90 & 5.95 & 6.00 & 5.78 & 5.48 \\
\hline & 15 & 5.43 & 5.65 & 5.88 & 5.88 & 5.75 & 5.63 & 5.45 \\
\hline & 10 & 5.20 & 5.50 & 5.60 & 5.65 & 5.73 & 5.55 & 5.33 \\
\hline & 5 & 5.00 & 5.20 & 5.45 & 5.38 & 5.20 & 5.23 & 5.05 \\
\hline
\end{tabular}

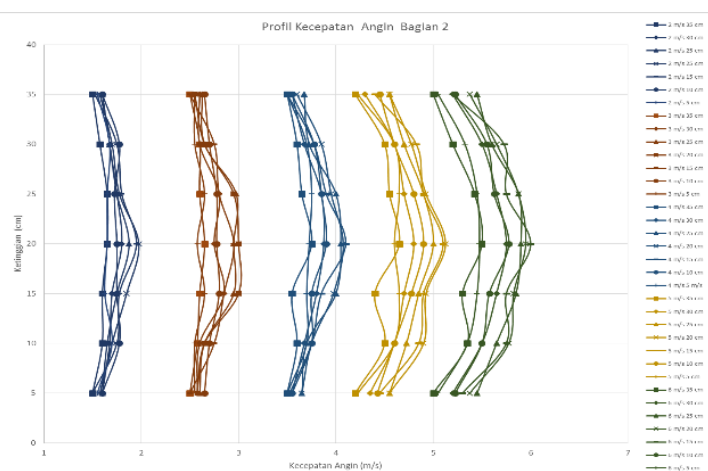

Gambar 4.4 Grafik profil kecepatan angin

\subsection{Analisis profil angin}

Analisis dari data hasil pengukuran kecepatan angin setiap titik uji meliputi rata-rata selisih setiap ketinggian, kesalahan setiap ketinggian, rata-rata kesalahan, standar deviasi, kecepatan rata-rata, kecepatan maksimum, dan kecepatan minimum. 
Profil kecepatan angin pada tabel 4.2 merupakan analisis dari tabel 4.1 menunjukan kecepatan angin tertentu menghasilkan kecepatan angin di titik uji yang berfluktuasi dengan kecepatan minimum dan maksimum yang berbeda-beda setiap ketinggian. Rata-rata selesih kecepatan angin tersebut sudah masuk dalam batas toleransi yang ditetapkan yaitu sebesar $\pm 0.5 \mathrm{~m} / \mathrm{s}$ meskipun pada ketinggian 5 $\mathrm{cm}$ dan $35 \mathrm{~cm}$ untuk kecepatan $4.06 \mathrm{~m} / \mathrm{s}, 5.04$ $\mathrm{m} / \mathrm{s}$ dan $6.01 \mathrm{~m} / \mathrm{s}$ selisihnya berada di luar batas toleransi. Intensitas turbulensi terkecil yaitu $4.56 \%$ pada kecepatan $4.06 \mathrm{~m} / \mathrm{s}$ dan intensitas tubulensi terbesar yaitu $6.55 \%$ pada kecepatan $2.04 \mathrm{~m} / \mathrm{s}$.

Tabel 4.2 Analisi profil kecepatan angin

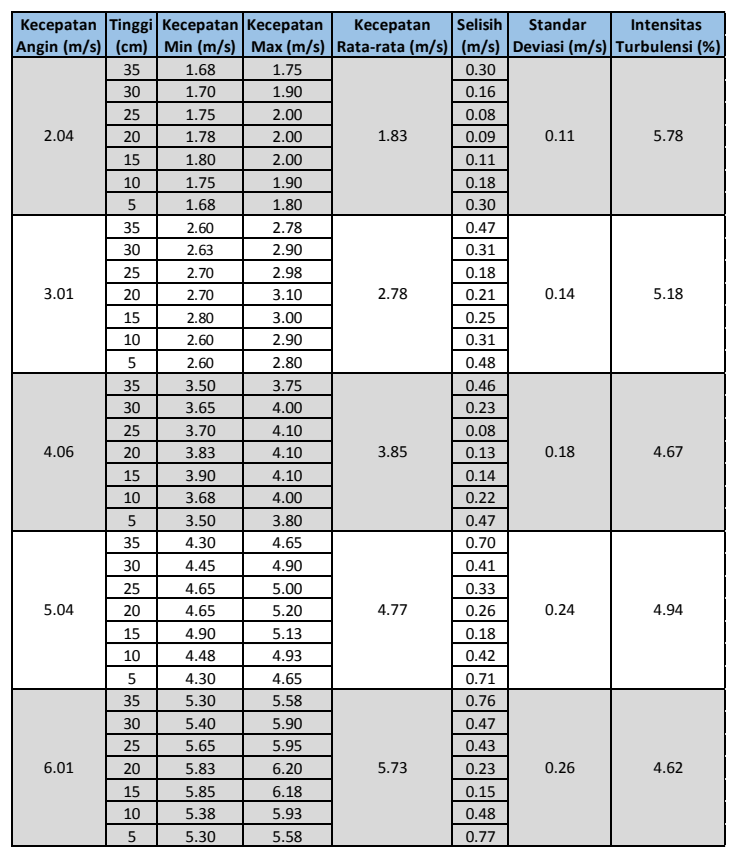

\section{KESIMPULAN DAN SARAN}

\subsection{Kesimpulan}

Kesimpulan dari hasil perancangan dan implementasi sistem serta hasil analisis terhadap prototipe wind tunnel sebagai berikut:

1. Prototipe wind tunnel memiliki panjang total $150 \mathrm{~cm}$, ukuran test section $40 \mathrm{~cm} \times$ $40 \mathrm{~cm} \times 45 \mathrm{~cm}$ dan diameter honeycomb $1.5 \mathrm{~cm}$ dengan aliran udara yang dihasilkan maksimum $6.50 \mathrm{~m} / \mathrm{s}$.

2. Hasil pengujian kecepatan angin pada titktitik dalam test section untuk memperoleh intensitas turbulensi $4.56 \%$ sampai 6.55 $\%$.
3. Prototipe wind tunnel dapat digunakan untuk proses kalibarasi karena penyimpangan kecepatan angin masih dalam toleransi yang telah ditetapkan $\mathrm{WMO}$ dan BMKG yaitu sebesar $\pm 0.5 \mathrm{~m} / \mathrm{s}$.

\subsection{Saran}

Saran untuk hasil perancangan dan implementasi sistem serta hasil analisis terhadap prototipe wind tunnel sebagai berikut:

1. Kecepatan angin maksimal yang dihasilkan di dalam wind tunnel hanya $6.50 \mathrm{~m} / \mathrm{s}$, untuk meningkatkan kecepatan angin lebih baik menggunakan motor listrik dengan kecepatan putar yang lebih tinggi atau menggunakan blade fan tipe centrifugal fan untuk daya hisap yang lebih tinggi.

2. Pengujian kecepatan angin titik-titik dalam test section lebih baik menggunakan tabung pitot untuk menghasilkan data yang lebih akurat.

3. Menambahkan Graphical User Interface untuk mempermudah pengaturan kecepatan angin dan kecepatan putar motor.

\section{DAFTAR PUSTAKA}

\section{Al-Shemmeri, T. T., 2012, Engineering Fluid Mechanics, Ventus Publishing ApS, Bookboon.}

Cattafesta, L., Bahr, C. J., dan Mathew, J., 2010, Fundamentals of Wind-Tunnel Design, Experimental Techniques for Fluid Dynamics and Thermal Science, Departement of Mechanical and Aerospace Engineering, University of Florida, Gainesville.

Hernandes, M. A. G., Lopez A. I. M., Jarzabek, A. A., Perales, J. M. P., Wu, Y., dan Xiaoxiao, S., 2013, Design Methodology for a Quick and Low-Cost Wind Tunnel, Ahmed, N. A., Wind Tunnel Designs and Their Diverse Engineering Applications, InTech, Croatia.

https://www.grc.nasa.gov/WWW/K-

12/airplane/shortt.html. Diakses pada tanggal 18 januari 2017.

Kundu, Pijush K. dan Cohen, Ira M., 2008, Fluid Mechanic, 4th ed. Elsevier Inc., British. 
Marpaung, Y. V., 2015, Aplikasi Perhitungan Hasil Kalibrasi dan Nilai Ketidakpastian Pengukuran dalam Sertifikat Kalibrasi Berbasis Visual Basic, Skripsi, Program Sarjana Terapan Instrumentasi, STMKG, Tangerang Selatan.

Republik Indonesia, 1992, Undang-undang Republik Indonesia nomor 31 Tahun 2009 tentang Meteorologi Klimatologi dan Geofisika Tahun 2009, Sekretariat Negara, Jakarta.

Riyadi, A. A., 2010, Pembuatan dan Pengujian Terowongan Angin Kecepatan Rendah Tipe Terbuka (Open Circuit Low Speed Wind Tunnel), Skripsi, Fakultas Teknik, Universitas Lampung, Bandar Lampung.

Shaleh, R., 2015, Analisis Pemilihan Fan dan Perhitungan Daya Motor pada Open Circuit Wind Tunnel, Skripsi, Fakultas Teknik Industri, Universitas Gunadarma, Depok.
Sofwan, A. dan Baqo, S. R., 2004, Sistem Pengendali Kecepatan Putaran Motor AC Phasa Satu Menggunakan Mikrokontroler AT89S8252, Proceeding Komputer dan Sistem Intelijen (KOMMIT2004), Auditorium Universitas Gunadarman, Jakarta.

Surya, P. B. dan Wailanduw, A. G., 2014, Pengaruh Variasi Screen terhadap Intensitas Turbulensi Wind Tunnel Tipe Open Circuit Subsonic di Jurusan Teknik Mesin Unesa, Jurnal Teknik Mesin. Volume 03 Nomor 02 Tahun 2014, 29-37.

Tjasyono H.K., Bayong, 2012, Meteorologi Indonesia Volume I, Badan Meteorologi Klimatologi dan Geofisika, Jakarta.

World Meteorological Organization, 2014, Guide to Meteorogical Instruments and Methods of Observation, 2014 edition, Geneva, Switzerlands. 